Dzieje Najnowsze, Rocznik L - 2018, 2

PL ISSN 0419-8824

Kim Christiaens

KADOC, KU Leuven (Belgia)

Idesbald Goddeeris

MoSa, KU Leuven (Belgia)

\title{
Solidarność i Trzeci Świat. Część II. Taktyczne sojusze z kluczowymi ruchami lat osiemdziesiątych XX wieku
}

\begin{abstract}
Abstrakt: Kontakty Solidarności z ruchami społecznymi lub politycznymi w Trzecim Świecie miały raczej ograniczony charakter oraz były bardzo wybiórcze. Solidarność zaakceptowała tylko te sprawy, które posiadały instrumentalną wartość dla jej pozycji międzynarodowej. Niechętnie uczestniczyła w walce przeciwko apartheidowi. Unikała wyraźnie antykomunistycznych ugrupowań. Było to widać nie tylko w jej niechęci do sprzymierzania się z opozycją antysandinistyczną w Nikaragui, ale także we współpracy z lewicową opozycją z Chile. W ten sposób Solidarność mogła uniwersalizować swoją sprawę, przeciwstawiając się polaryzacji ładu zimnowojennego oraz pokazać, że była częścią ogólnej walki antytotalitarnej.
\end{abstract}

Słow a kluc z ow e: Solidarność, Nikaragua, Chile, RPA, Apartheid.

Abstract: Solidarność's contacts established with social and political movements in the Third World were rather limited and highly selective. Solidarność only embraced causes that were instrumental to its international profile. It reluctantly sided with the anti-apartheid struggle. It also avoided explicitly anti-communist groups. This became not only clear in its reluctance to side with the anti-Sandinista opposition in Nicaragua, but also in its collaboration with the left-wing opposition from Chile. In this way, Solidarność could universalise its cause, defy the Cold War bipolarity, and demonstrate that it was part of a general anti-totalitarian struggle.

Key w ords: Solidarność, Nicaragua, Chile, South Africa, Apartheid. 


\section{Wstęp}

W pierwszej części artykułu, która ukazała się w poprzednim numerze tego czasopisma, dyskutowaliśmy o tym, jak Solidarność, niemal tuż po jej powstaniu, zwróciła się w stronę związków zawodowych w Ameryce Łacińskiej, mianowicie Centralnego Łacińsko-Amerykańskiego Związku Zawodowego (Central Latinoamericano de Trabajadores - CLAT), regionalnej konfederacji skupiającej chrześcijańskie związki zawodowe. Pomimo publicznych deklaracji i uroczystości celebrujacych wzajemna solidarność, bardziej szczegółowe badania pokazuja, że współpraca ta miała jednak głównie instrumentalny charakter i zorganizowana została głównie przez Światowa Konfederację Pracy (ŚKP). Ta ostatnia była relatywnie niewielka instytucją międzynarodowa skupiająca związki zawodowe, w dodatku zajmujacca się przede wszystkim poszukiwaniem alternatywnych sposobów ochrony interesów świata pracy. Spraw Solidarności w Ameryce Łacińskiej nie traktowała priorytetowo.

Wyniki naszych badań nie pozwoliły nam jednak opowiedzieć się po którejś ze stron akademickiej debaty prowadzonej na temat ponadnarodowych kontaktów Solidarności. Musieliśmy zgodzić się zarówno ze zwolennikami poglądu o globalnych zainteresowaniach polskiej opozycji, ale także z takimi krytykami, jak Noam Chomsky, który odmawia Solidarności i innym wschodnioeuropejskim ruchom opozycyjnym powszechnej wrażliwości i związków z Południem. W niniejszym artykule wskażemy na kolejne argumenty w tej debacie, analizując postawy Solidarności wobec trzech najbardziej przyciagających uwagę opinii publicznej na świecie kryzysów w latach osiemdziesiątych: wojny domowej w Nikaragui, dyktatury Pinocheta w Chile i walki z apartheidem w RPA.

\section{Nikaragua: paradoksalne zaniedbanie}

Solidarność nie wszędzie była witana z wielkim entuzjazmem. Stało się to szczególnie widoczne w Nikaragui, gdzie Sandinistowski Front Wyzwolenia Narodowego (Frente Sandinista de Liberación Nacional, Sandinista National Liberation Front - FSLN) sprawował władzę od czasu obalenia dyktatury Somozy w 1979 r. i gdzie okrutna wojna domowa między marksistowskim reżimem a wspieranymi przez rząd USA rebeliantami Contras wstrząsała całym krajem. Józef Przybylski i Tadeusz Konopka podróżując po Ameryce Łacińskiej w styczniu 1982 r., planowali odwiedzić Nikaraguę, ale nie pozwolono im opuścić samolotu na lotnisku w Managui. Władze sandinistyczne dystansowały się od światowego zamieszania wokół kryzysu w Polsce. Żeby jednak spotkać się z Konopką i Przybylskim, opozycyjni liderzy związkowi z Nikaragui pojechali do Kostaryki i Hondurasu¹. We wrześniu 1982 r. Carlos

1 T. Konopka, Uwagi po podróży członków Solidarności do krajów Ameryki Łacińskiej, niewydany rękopis, Rzym, 19 III 1981 r., s. 1-2, 14. 
Huembes, lider chrześcijańskiego związku zawodowego, spotkał się również z polska delegacja podczas konferencji zorganizowanej przez CLAT w Wenezueli na temat sytuacji w Polsce ${ }^{2}$. Nikaraguańska opozycja rzeczywiście była gotowa identyfikować się z Solidarnościąa . Ten sojusz wydawał się logiczny, biorąc pod uwagę oczywiste podobieństwa. Oba ruchy dotknęły represje ze strony reżimu marksistowskiego. Podobnie jak Polacy, nikaraguańska opozycja robotnicza, prowadzona przez chrześcijańsko-demokratyczne i socjaldemokratyczne związki zawodowe, koncentrowała się na walce w obronie związków zawodowych i praw człowieka, a także wspierana była przez Międzynarodowa Konfederację Wolnych Związków Zawodowych (MKWZZ) i ŚKP oraz ich członków w Europie Zachodniej. Dodatkowy czynnik upodabniajacy stanowiły ciagłe stany wyjątkowe, podczas których sandiniści rządzili krajem, co pod wieloma względami przypominało wprowadzenie stanu wojennego w Polsce w grudniu 1981 r., a także bliskie relacje sandinistów z blokiem radzieckim. Moskwa i inne reżimy komunistyczne były kluczowe dla ekonomicznego i politycznego przetrwania Nikaragui w czasie głębokiego chaosu wojny domowej i amerykańskiego bojkotu ${ }^{4}$.

Władze PRL również utrzymywały dobre relacje z Nikaragua. Angażowały się w państwowa propagandę i kampanie solidarności w poparciu dla FSLN, tak samo jak wcześniej robiły to w takich sprawach, jak wojna w Wietnamie lub opór przeciwko Pinochetowi ${ }^{5}$. Rozwinęły również z Nikaragua przyjacielskie stosunki. W samym tylko $1984 \mathrm{r}$. w obydwu krajach doszło do ośmiu oficjalnych wizyt. Pięć nikaraguańskich delegacji przyjechało do Polski: minister planowania, członek junty Rafael Córdova Rivas, koordynator junty Daniel Ortega wraz z ministrem spraw zagranicznych, delegacja wojskowa i minister spraw wewnętrznych, a trzech polskich polityków pojechało do Nikaragui: minister spraw zagranicznych Stefan Olszowski, premier Wojciech Jaruzelski i wicepremier Mieczysław Rakowski ${ }^{6}$. Ten ostatni pisał o swojej wizycie w dziennikach (12-15 października). Spotkał się z wieloma politykami i reprezentantami organizacji społecznych i stwierdził, że „rozmowa z sandinistami [...] to wielka przyjemność"7. Prawdą jest natomiast, że PRL równocześnie sprzedawała broń dla Contras, którzy walczyli z reżimem sandinistycznym $\mathrm{z}$ amerykańskim wsparciem. Takie oskarżenia padły

\footnotetext{
${ }^{2}$ International Institute of Social History [Międzynarodowy Instytut Historii Społecznej w Amsterdamie (dalej: IISH)], Solidarność Nederland, 49, „CLAT Newsletter”, IX 1982.

${ }^{3}$ Centrum Dokumentacyjne i Badawcze Religii, Kultury i Społeczeństwa w Leuven (Belgia) (dalej: KADOC), Archiwum Światowej Konfederacji Pracy (dalej: WCL), 327, Central De Trabajadores de Nicaragua, Nobel de la Paz 1983 Lech Wałęsa, 1983.

${ }^{4}$ Zob. np.: Aufbruch nach Nicaragua. Deutsch-deutsche Solidarität im Systemwettstreit, Hrsg. E. Harzer, W. Volks, Berlin 2008.

${ }^{5}$ R. Samsel, Dotrzeć do bunkra Somozy, Warszawa 1980.

${ }^{6}$ Ministerstwo Spraw Zagranicznych (dalej: MSZ), Księga Nabytków i Ubytków, nr 58/86, 1984.

${ }^{7}$ M.F. Rakowski, Dzienniki polityczne 1984-1986, Warszawa 2005, s. 141.
} 
już w 1987 r. w artykułach, jakie się ukazywały w „Los Angeles Times” od lutego, a także w raporcie parlamentarnym opublikowanym $\mathrm{w}$ listopadzie. Historyk Przemysław Gasztold-Seń znalazł niedawno nowy dowód w archiwach polskich służb specjalnych, potwierdzający tajne kontakty i łaczacy je z Monzer al-Kassar, syryjskim międzynarodowym handlarzem bronia, który był również uwikłany w aferę Iran-Contras ${ }^{8}$. Jednak dla opozycji polskiej i nikaraguańskiej sprawa ta pozostawała raczej nieznana i przez to mniej istotna. W ich oczach Managua i Warszawa były bliskimi współpracownikami.

Wszystko to powodowało, że opozycja nikaraguańska chętnie identyfikowała się z dysydentami polskimi. Po grudniu 1981 r. dysydenci nikaraguańscy nazwali się nawet „Polakami Ameryki Centralnej” i dokonali porównania pomiędzy rządem sandinistów, który używał przemocy, aby kontrolować nieposłuszne części społeczeństwa, a militarną akcją w celu pokonania Solidarności w Polsce ${ }^{9}$. Szczególnie chrześcijańsko-demokratyczny ruch związkowy Centrala Robotników Nikaragui (Central de Trabajadores de Nicaragua CTN), członek CLAT, łączył wezwania poparcia dla Solidarności z publicznym potępianiem „polskiego syndromu” w Ameryce Centralnej ${ }^{10}$.

Zarazem Solidarność nie uważała, że w jej interesie leżało identyfikowanie się ze sprawą nikaraguańską i nawet sprzeciwiała się takim powiązaniom. Istnieje kilka wytłumaczeń dla tej z pozoru paradoksalnej sytuacji. Po pierwsze, bezpośredni kontakt z opozycją w Nikaragui był trudny z powodu barier wprowadzonych przez reżim sandinistów i nikłej obecności opozycji nikaraguańskiej na uchodźstwie na Zachodzie. Po drugie, polska propaganda komunistyczna przyczyniała się do pozytywnego wizerunku FSLN w prasie polskiej, która obszernie informowała o amerykańskim uwikłaniu w okrucieństwa podczas wojny z Contras. Nawet jeśli trudno ocenić efektywny wpływ tej propagandy na społeczeństwo, wiadomo, że Solidarność miała niewiele możliwości w kształtowaniu odmiennych opinii. Trzeci - i najważniejszy powód był jednak taki, że reżim w Nikaragui cieszył się dużą sympatią na Zachodzie, nie tylko w skrajnie lewicowych kręgach, ale również wśród zwolenników Solidarności. Oni także dostrzegali podobieństwa pomiędzy Polska i Nikaragua, ale w sposób zupełnie odmienny od tego, w jaki widziała je opozycja nikaraguańska. Wielu obserwatorów w Europie Zachodniej ironicznie wskazywało na takie podobieństwa pomiędzy Polską i Nikaraguą, które skłaniały nie do ataku, ale do wsparcia sandinistów. Dla wielu działaczy

${ }^{8}$ P. Gasztold-Seń, Biznes z terrorystami. Brudne interesy wywiadu wojskowego PRL $z$ bliskowschodnimi organizacjami terrorystycznymi, „Pamięć i Sprawiedliwość” 2014, nr 1, s. 183, 195-196, 207.

${ }^{9}$ Central Latinoamericano de Trabajadores [Centralny Łacińsko-Amerykański Zwiąek Zawodowy (dalej: CLAT)], „Nicaragua. El syndrome de Polonia”, Departamento de información y publicaciones, Boletín de Prensa-Radio y Televisión, 29 XII 1981.

${ }^{10}$ KADOC, WCL, 328, Central de Trabajadores de Nicaragua, Lech Wałęsa. Nobel de la Paz, 7 X 1983. 
pacyfistycznych zwalczających instalowanie broni rakietowej w Europie Zachodniej bitwa przeciw amerykańskiej interwencji w Nikaragui nie tylko przypominała walkę Solidarności przeciwko Związkowi Radzieckiemu, ale przede wszystkim ich własna walkę vis-à-vis zimnej wojny Reagana. Podczas wizyty w Nikaragui zachodnioniemiecki pisarz Günter Grass wskazał na porównanie, które stało się potem bardzo popularne w Europie Zachodniej, mianowicie wojny sandinistów przeciwko amerykańskiej interwencji z walka polskiej opozycji przeciw wspieranemu przez Sowietów rządowi Jaruzelskiego ${ }^{11}$. W podobnym sposobie myślenia, wychodzącym poza zimną wojnę, niektóre zachodnioeuropejskie socjaldemokratyczne związki zawodowe, takie jak Organizacja Narodowa w Szwecji (Landsorganisationen i Sverige - LO), nie widziały żadnej sprzeczności odnoszącej się do finansowania projektów rozwojowych reżimu sandinistycznego w Nikaragui i wspierania Solidarności, chociaż podważano to $\mathrm{w}$ konfliktach pomiędzy oficjalną antykomunistyczna polityką przywódców MKWZZ a sympatiami, jakie żywili zwykli członkowie związku do sandinistów.

Nawet wśród członków Solidarności istniał życzliwy stosunek do FSLN. Na przykład Zbigniew Marcin Kowalewski, polski uchodźca we Francji z trockistowskimi sympatiami, organizował kampanie solidarności dla sandinistów, został jednak wykluczony z paryskiego Komitetu Koordynacyjnego Solidarności ${ }^{12}$. Przywództwo związku było niechętne wysiłkom łaczenia obu spraw. Odrzucało wizję Grassa oraz plany zachodnioeuropejskich działaczy pacyfistycznych ${ }^{13}$, żeby włączyć polskich oraz innych wschodnioeuropejskich dysydentów w kampanie przeciwko polityce Reagana w Ameryce Centralnej ${ }^{14}$. Porównywanie się $\mathrm{z}$ sandinistami było sprzeczne $\mathrm{z}$ zasadami stosowanymi przez ruch, który na Zachodzie otrzymywał wsparcie od najbardziej zagorzałych krytyków sandinistów (Reagan, Thatcher i chrześcijańscy demokraci). W dodatku umieściłoby Solidarność w tym samym obozie co rząd polski.

Sojusz z opozycją nikaraguańską także nie był dobra opcją. Wprowadziłby możliwość polaryzacji zamiast uniwersalizacji sprawy Solidarności i naraziłby na ryzyko delikatną współpracę z zachodnią lewica. Dyskredytowałby opozycję polska przez występowanie z oskarżeniami - zarówno ze strony propagandy państwowej na Wschodzie, jak również radykalnej lewicy na Zachodzie - że stanowiła spisek CIA. Wszystkie te argumenty są kluczowe dla zrozumienia

${ }^{11}$ G. Grass, Im Hinterhof. Bericht über eine Reise nach Nicaragua, „Die Zeit”, 1 X 1982, s. 45.

${ }_{12}$ M. Phelps, Solidarność in Łódź: An Interview with Zbigniew Marcin Kowalewski, „International Labor and Working-Class History" 2008, vol. LXXIII, no. 1, s. 106-113. Na temat Kowalewskiego zob. też: I. Goddeeris, Ministerstwo Spraw Zagranicznych „Solidarności”: Biuro Koordynacyjne NSZZ „Solidarność”, 1982-1989, cz. 1, „Pamięć i Sprawiedliwość” 2006, nr 2, s. 322-323.

${ }^{13}$ „Istnieja granice sity”. Rozmowa „Przegladu Politycznego” z Günterem Grassem, „Przegląd Polityczny" 1984, nr 3, s. 3-15.

${ }^{14}$ P. Kenney, A Carnival of Revolution. Central Europe 1989, Princeton-Oxford 2002, s. 119. 
zagadnienia, dlaczego Solidarność, pomimo szans na wspólną walkę, czy to przeciwko „czerwonym dyktaturom”, czy to zimnowojennej dwubiegunowości, unikała sprawy Nikaragui i omijała sytuacje, w których porównywana była z opozycją nikaraguańską lub sandinistami. Czynniki te pomagają natomiast wyjaśnić, dlaczego istniał opór wobec prawicowego reżimu w Trzecim Świecie, do którego zaliczano Chile rządzone przez Pinocheta, i dlaczego sprawa ta stała się najważniejszą kwestią międzynarodowa, jaką zajmowała się Solidarność w latach osiemdziesiątych.

\section{Chile: walka z generałami i poszukiwanie lewicy}

Żadna sprawa w Trzecim Świecie nie stała się tak ważna dla Solidarności, jak opór wobec dyktatury Pinocheta w Chile. To kolejny paradoks. Wiadomo, że Polska i Chile były autorytarnymi reżimami, w których generałowie $\mathrm{w}$ ciemnych okularach używali aparatu państwowego w celu represjonowania opozycji, a szczególnie związków zawodowych. Poza tym jednak niewiele łączyło oba, oddalone od siebie o tysiące kilometrów, kraje. W przeciwieństwie do Polski Chile miało prawicowy reżim antykomunistyczny, a opozycja identyfikowała się z Salvadorem Allende Gossens, poprzednim prezydentem, który zacieśnił relacje z blokiem komunistycznym, został usunięty i zabity, i zapamiętano go jako męczennika socjalizmu ${ }^{15}$. Duża część powstałych po przewrocie w 1973 r. opozycyjnych struktur na uchodźstwie kierowana była przez członków zakazanych chilijskich partii komunistycznych i socjalistycznych, których główne siedziby znajdowały się w takich miastach, jak Berlin Wschodni i Moskwa, i które otrzymywały wsparcie od rządów Europy Wschodniej, włącznie z rządem polskim ${ }^{16}$.

Jednak dokładnie ten związek z obozem komunistycznym, a szczególnie jego zauważalnie wzmagający się, kontestowany charakter spowodował, że polski kryzys tak głęboko i widocznie zaznaczył się w opozycji chilijskiej ${ }^{17}$. Pojawienie się i zniszczenie Solidarności stało się z czasem głównym punktem zapalnym debat na temat relacji pomiędzy socjalizmem i demokracją a strategiami walki z Pinochetem. Te debaty coraz bardziej dzieliły opozycję chilijska zarówno w kraju, jak i za granica. W socjalistycznej Partii Chile (Partido Socialista de Chile - PSCh, czyli najważniejsza zagraniczna partia w Europie

15 T. Harmer, Allende's Chile and the Inter-American Cold War, Chapel Hill 2011.

16 J.E. Pieper Mooney, East Germany: Chilean Exile and the Politics of Solidarity in the Cold War, w: European Solidarity with Chile, 1970s-1980s, ed. K. Christiaens, I. Goddeeris, M. Rodríguez García, Frankfurt am Main 2014, s. 275-300; Y. Gradskova, The Soviet Union: 'Chile is in Our Hearts.' Practices of Solidarity between Propaganda, Curiosity, and Subversion, w: European Solidarity with Chile..., s. 329-346.

${ }^{17}$ I. Walker, Socialismo y democracia: Chile y Europa en perspectiva comparada, Santiago 1990, s. 186-187. 
Zachodniej i Wschodniej) pod koniec lat siedemdziesiątych doszło do podziału na proradziecka grupę zmierzająca do współpracy z Komunistyczna Partia Chile (Partido Comunista de Chile - PCCh) i bardziej umiarkowanych socjalistów pod przywództwem Carlosa Altamirano. Ten ostatni łączył marksizm nie z walka zbrojna, ale z demokracja, popierał szeroki sojusz z chrześcijańskimi demokratami, a także uzyskał dominująca pozycję $\mathrm{w}$ organizacjach emigracyjnych w Europie Zachodniej ${ }^{18}$. Podczas gdy proradzieccy socjaliści i lider Komunistycznej Partii Chile Luís Corvalán cieszyli się z przewrotu Jaruzelskiego, widząc w tym sposób na ochronę socjalizmu w Polsce, i kontynuowali współpracę z obozem radzieckim ${ }^{19}$, umiarkowani socjaliści chętnie identyfikowali się z Solidarnością i starali się wyciagnąć wnioski z jej losu ${ }^{20}$.

Już w 1981 r. Altamirano udał się w podróż do Warszawy, żeby spotkać się z Wałęsa, wyrazić solidarność z opozycją w Polsce i podkreślić wspólną wiarę w potęgę demokracji, pokojowego oporu i masowej opozycji ${ }^{21}$. Chilijscy uchodźcy polityczni mieszkajaccy w Polsce i związani z poglądami Altamirano sympatyzowali z Solidarnością i nawet brali udział w jej pracach do tego stopnia, że niektórzy z nich zostali zmuszeni do opuszczenia kraju ${ }^{22}$. Kryzys z grudnia 1981 r. i następujące po nim represje w Polsce były uważnie obserwowane przez główne organizacje emigracyjne umiarkowanych socjalistów, chrześcijańskich demokratów i inne. Jedność z Solidarnością pozwoliła im zdystansować się od prosowieckich organizacji emigracyjnych i odrzucić piętno komunistyczne, które chilijska propaganda państwowa oraz apologeci Pinocheta na Zachodzie przypisali całej opozycji chilijskiej. Okazała się jednak również niezręczna sprawa. Nie tylko dlatego, że poszerzała przepaść do proradzieckich socjalistów i komunistów i utrudniała wysiłki na rzecz jedności, ale również dlatego, że Pinochet publicznie potępił rząd Jaruzelskiego i włączył polski kryzys do swojego dyskursu antykomunistycznego. Wszystko to zachęciło opozycję chilijską do łączenia jedności z Solidarnością nie tylko z krytyką marksizmu-leninizmu, ale również z antyamerykanizmem. Po ogłoszeniu stanu wojennego „Chile-América” oraz „Convergencia”, dwa główne czasopisma opozycyjne wydawane przez chilijską chrześcijańską demokrację i umiarkowanych socjalistów na emigracji, przypisały klęskę i delegalizację Solidarności zagranicznym interwencjom w Polsce Związku Radzieckiego i Stanów Zjednoczonych ${ }^{23}$.

${ }^{18}$ Exiliados, emigrados y retornados. Chilenos en América y Europa, 1973-2004, ed. J. del Pozo, Santiago 2006; K. Hite, When the Romance Ended: Leaders of the Chilean Left, 1968-1998, New York 2000, s. 47-49.

19 Zob. np.: „Chile-América” 1982, nro. 76-77, s. 56; „Convergencia. Revista del socialismo chileno et latinoamericano" 1982, nro. 5-6, s. 23.

${ }^{20}$ Declaración sobre Polonia, „Chile-América” 1982, nro. 76-77, s. 7.

${ }^{21}$ H. Muñoz, The Dictator's Shadow. Life Under Augusto Pinochet, New York 2006, s. 126.

${ }^{22}$ I. Walker, op. cit., s. 187.

${ }^{23}$ Nuestra solidaridad con el pueblo polaco, „Convergencia”, XI 1981 - I 1982, nro. 5-6, s. 29-30; „Chile-América” 1982, nro. 76-77, s. 35-36. 
Paralele pomiędzy Chile i Polską nie miały jedynie ideologicznego charakteru, ale zakorzeniły się również $\mathrm{w}$ zmianach, jakie zachodziły $\mathrm{w}$ Chile. Ponieważ partie opozycyjne były zakazane, związki zawodowe, a szczególnie Narodowa Koordynacja Zwiazkowa (Coordinadora Nacional Sindical - CNS) kierowana przez chilijskich chrześcijańskich robotników, od końca lat siedemdziesiątych zaczęły ucieleśniać wewnętrzną opozycję przeciwko Pinochetowi. Neoliberalna polityka rządu i restrykcyjne ustawodawstwo pracy przygotowały wraz z kryzysem ekonomicznym lat osiemdziesiątych bardzo płodny grunt, żeby zjednoczyć duże części społeczeństwa popierajace program na rzecz demokracji i praw człowieka. W swoim pokojowym charakterze różniły się radykalnie od zmarginalizowanych marksistowskich grup i partii opozycyjnych wspierających zbrojny opór ${ }^{24}$. Ta odbudowa opozycji wokół związków zawodowych, a także rosnące represje nie tylko zmieniły naturę i orientację międzynarodowych kampanii przeciwko Pinochetowi, organizowanych przez chilijskich emigrantów i ich sojuszników w Europie Zachodniej, ale także uczyniły podobieństwa z polską opozycją związkową przeciwko Jaruzelskiemu bardziej oczywiste. Nic dziwnego zatem, że najbardziej istotny łącznik z Solidarnością powstał dzięki chilijskiej opozycji związkowej.

Już kilka dni po delegalizacji Solidarności chrześcijański pracownik przemysłu tekstylnego i czołowy opozycjonista Manuel Bustos wysłali z więzienia w Santiago wyraz solidarności z Lechem Wałęsą do MKWZZ, która zebrała się w Brukseli w celu przedyskutowania kampanii dla poparcia Solidarności $i^{25}$. W listopadzie 1982 r. CNS planowała zorganizować wiec solidarności, który ostatecznie został zakazany przez rząd chilijski ${ }^{26}$. Polska wciąż pozostała inspirującym symbolem dla chilijskiego ruchu związkowego, a Chilijczycy stworzyli nawet dwie wersje „własnego Wałęsy”. Socjalistyczny lider związkowy Tucapel Jiménez, który na wzór Polski starał się stworzyć szeroką opozycje zwiąkowa, został zamordowany przez wojsko w $1982 \mathrm{r.}^{27}$ Po jego śmierci Rodolfo Seguel, młody przywódca Narodowego Komanda Robotników (Comando Nacional de Trabajadores - CNT), które od 1983 r. mobilizowało tysiące obywateli w masowych demonstracjach i strajkach narodowych, zaczą być nazywany, zarówno w kraju, jak i za granica, drugim „chilijskim Lechem Wałęsa”" ${ }^{2}$. To porównanie opierało się nie tylko na ikonicznych wąsach i charyzmie obu katolickich związkowców, ale także na strategicznych przesłankach i inspiracji, jaką Wałęsa dał Seguelowi. Widział

${ }^{24}$ Victims of the Chilean Miracle. Workers and Neoliberalism in the Pinochet Era, 1973-2002, ed. P. Winn, Durham-London 2004.

25 „Chile-América” 1982, nro. 76-77, s. 56.

${ }^{26}$ „ILO Interim Report”, VI 1983, no. 226, Case no. 1170 (Chile), 3 XII 82, http://www.ilo.org/ dyn/normlex/en/f?p=NORMLEXPUB:50002:0::NO::P50002_COMPLAINT_TEXT_ID:2900919.

27 S. Bizzarro, Historical Dictionary of Chile, Lanham 2005, s. 677.

28 J. Edwards, Chile: El dificil retorno a la democracia, „Revista de la Universidad de México” 1984, nro. 34, s. 12; „Der Spiegel”, 27 VI 1983. 
go wraz z Gandhim jako przykład potęgi „walk bez przemocy, które przyniosły lepsze rezultaty niż zbrojne konfrontacje" 29 .

Strona polska także przykładała wielką wagę do opozycji przeciwko Pinochetowi. Chile rzeczywiście stało się pierwszą i najważniejszą sprawa międzynarodowa, jaką zajęła się opozycja polska po grudniu 1981 r. Już na początku 1982 r. Wałęsa odpowiedział na deklarację solidarności Bustosa. Wyraził swoje wsparcie dla chilijskiej opozycji pracowniczej oraz potępił uwięzienie Bustosa i komunistycznego związkowca Alamira Guzmána ${ }^{30}$. Jeden z najbardziej symbolicznych aktów skierowanych do opozycji chilijskiej stanowiło zaproszenie przez Wałęsę Seguela na uroczystość wręczenia Pokojowej Nagrody Nobla w Oslo w 1983 r. ${ }^{31}$ Z powodu barier stworzonych przez oba reżimy bezpośrednie kontakty pomiędzy chilijskimi i polskimi liderami opozycji były jednak rzadkie i niemal zawsze zapośredniczone przez wspólnych sojuszników, głównie MKWZZ i ŚKP, a także wizytujących związkowców z Europy Zachodniej ${ }^{32}$.

Istniała również bardziej trwała i bezpośrednia współpraca, która głównie została nawiązana pomiędzy polskimi i chilijskimi uchodźcami w Europie Zachodniej. Kilka miesięcy po powołaniu Biura Koordynacyjnego NSZZ „Solidarność” za Granicą w lecie 1982 r., Chilijczycy utworzyli podobną organizację, która miała koordynować kampanie międzynarodowej solidarności z chilijskimi opozycyjnymi związkami zawodowymi. Chilijski Komitet Pracy został utworzony w Rzymie na początku 1983 r. przez Bustosa. Związki z Polakami były jasne: Bustos w grudniu 1982 r. spotkał się w Brukseli z Jerzym Milewskim, który natomiast odbył spotkanie z Seguelem w Rzymie $^{33}$. Chilijski Komitet Pracy szybko przeprowadził się do Brukseli, gdzie otrzymał biuro od socjalistycznego związku zawodowego Belgijska Powszechna Federacja Pracy (Algemeen Belgisch Vakverbond/ Fédération Générale du

${ }_{29}$ P. Ackerman, J. DuVall, A Force More Powerful. A Century of Non-Violent Conflict, New York 2001, s. 291.

${ }^{30}$ M.H. Spooner, Soldiers in a Narrow Land: The Pinochet Regime in Chile, Berkeley 1999, s. 168; „Latijns-Amerika” 1982 , nr. 1, s. 6.

31 Wspomniane z powodu jej „decydującego znaczenia” w wywiadzie udzielanym przez Carlosa Limę, lidera chilijskiego związku zawodowego budowniczych, przebywającego na uchodźstwie we Włoszech od 1974 r. T. Konopka, Chile i Polska. Rozmowa z Carlosem Lima, „Widnokrag” 1987, nr 6/7, s. 59.

${ }^{32}$ Zob. np.: KADOC, WCL, 327, Zapiski z rozmowy Günthera Engelmayera z Lechem Wałęsa, 20 XII 1983.

${ }^{33}$ K. Christiaens, The Difficult Quest for Chilean Allies. International Labor Solidarity Campaigns for Chile in the 1970s and 1980s, w: European Solidarity with Chile..., s. 97-129; „Free Labour World” 1983, no. 391/392, s. 6. Milewski pojechał do Rzymu w drugiej połowie 1982 r. m.in. po to, żeby dążyć do współpracy z Chile. Instytut Pamięci Narodowej (dalej: IPN), 01521/2175, W. Gontarski, „Biuro Koordynacyjne NSZZ «Solidarność» za Granica w Brukseli”, nieopublikowana praca magisterska, Akademia Spraw Wewnętrznych, Instytut Kryminalistyki i Kryminologii, Warszawa 1989, s. 68. 
Travail de Belgique - ABVV/FGTB), podczas gdy Biuro Koordynacyjne NSZZ „Solidarność” za Granica dzieliło biuro z belgijskim Powszechnym Chrześcijańskim Związkiem Zawodowym/ Konfederacją Chrześcijańskich Związków Zawodowych (Algemeen Christelijk Vakverbond/ Confédération des syndicats chrétiens - ACV/CSC) ${ }^{34}$. W Brukseli bliska relacja nawiązała się pomiędzy Milewskim i jego współpracownikami w Biurze Koordynacyjnym NSZZ „Solidarność” za Granicą a chilijskim socjaldemokratycznym związkowcem Luisem Menesesem, który zastapił Bustosa pełniącego funkcje prezydenta Chilijskiego Komitetu Pracy, po tym jak ten ostatni wrócił do Chile. Zgodnie z deklaracją solidarności ogłoszona przez Bustosa i Milewskiego podczas spotkania w Brukseli w grudniu 1982 r., Chilijczycy i Polacy uczestniczyli razem w międzynarodowych konferencjach zorganizowanych przez konfederacje związków zawodowych, w delegacjach wysyłanych na coroczną konferencję Międzynarodowej Organizacji Pracy (MOP; ILO) w Genewie oraz udzielali wywiadów dla prasy, w których podkreślali wspólną tożsamość.

Tak jak chilijska opozycja związkowa wykorzystywała jedność z Solidarnościa, żeby bronić samej siebie przed oskarżeniami ze strony Pinocheta o infiltrację komunistyczną i zagrożenia dla bezpieczeństwa narodowego, tak samo ta wspólna tożsamość pomiędzy opozycja chilijską i polską łączyła się z polskim strategicznym celem, jakim było przełamanie „logiki bloków”35. Jak podkreślił Milewski we wspólnym wywiadzie z Bustosem, sojusz z chilijskim oporem przeciwko Pinochetowi musiał dowodzić w jasny sposób, że Solidarność na pewno nie była sprawa prawicowego i klerykalnego ruchu reakcyjnego ani „spisku CIA”, jak próbowali to przedstawić wschodnioeuropejska propaganda państwowa i lewicowi krytycy na Zachodzie ${ }^{36}$. W jego opinii łaczność z Chile wydawała się strategicznie ważna, żeby pokazać wyraźnie, że Solidarność była częścią antytotalitarnej walki w krajach, „gdzie nie istnieje lewica i prawica" ${ }^{37}$. Wszystko to przypominało dyskurs radzieckiego dysydenta Włodzimierza Bukowskiego o prawach człowieka, zwolnionego z więzienia przez Związek Radziecki w 1976 r. w zamian za uwięzionego chilijskiego komunistę Luisa Corvalána, i potwierdzało szeroko cytowane przez polskich opozycjonistów stwierdzenie, że „on nie był z prawicy ani lewicy, tylko z obozu koncentracyjnego" ${ }^{38}$.

${ }^{34}$ I. Goddeeris, Ministerstwo Spraw Zagranicznych..., cz. 2, s. 343.

${ }^{35}$ R. Brier, Poland's Solidarity as a Contested Symbol of the Cold War: Transatlantic Debates After the Polish Crisis, w: European Integration and the Atlantic Community in the 1980s, ed. K.K. Patel, K. Weisbrode, New York 2013, s. 97-100.

36 „Free Labour World” 1983, no. 391/392, s. 6-9.

${ }^{37}$ IPN, BU 01820/49, t. IV, wywiad z Jerzym Milewskim, Radio Wolna Europa, 6 II 1985, s. $111 \mathrm{i} \mathrm{n}$.

38 „D'ici - d'est. Bulletin du comité du $1^{\text {er }}$ mai, pour les libertés démocratiques et les droits des travailleurs dans les pays de l'est", II 1983, n 18/19; A. Michnik, Letters from Prison and other Essays, Berkeley 1987, s. 91. 
Co ciekawe, przez akt solidarności z Chile polski związek zawodowy zaangażował się w rodzaj czegoś, co Siergiej Uszakin określił „mimetycznym oporem" ${ }^{39}$. Polski i inne wschodnioeuropejskie rządy przez lata chwaliły solidarność międzynarodowa $\mathrm{z}$ oporem przeciwko Pinochetowi ${ }^{40}$, a tym razem to Solidarność przejęła ten dyskurs. Propaganda państwowa zmieniła się tym sposobem w bumerang uderzający w sam reżim. O ile okazała się skuteczna w przypadku Nikaragui, o tyle rzecz się miała odwrotnie w sytuacji Chile. Działo się tak dlatego, że opór w stosunku do Pinocheta był znacznie mniej kontrowersyjnym i znacznie bardziej uniwersalnym symbolem w walce o prawa człowieka i demokrację. W obozie opozycji polskiej różne nurty, poczynając już w latach siedemdziesiątych od Komitetu Obrony Robotników (KOR), łączyły się w walce przeciwko Pinochetowi.

Chile dawało nie tylko możliwość uniwersalizacji oporu wobec Jaruzelskiego i do przeciwstawienia się polaryzacji ładu zimnowojennego, ale również zwiększało tragiczny charakter polskiego kryzysu. Przez przedstawianie Polski jako drugiego Chile opozycja polska starała się podważyć te rosnące głosy w Europie i USA, które zaczęły skłaniać się w stronę polityki normalizacji prowadzonej przez Jaruzelskiego w połowie lat osiemdziesiątych. Chociaż represje w Polsce nie powinny być pomniejszane, aresztowania, procesy pokazowe i zdarzające się morderstwa jednak bladły w porównaniu z tysiącami zabitych i zaginionych, którzy stali się i wtedy wciąż stawali się ofiarami represji Pinocheta ${ }^{41}$.

Ostatnim czynnikiem, który wpłyną na stosunek pomiędzy Solidarnością a Chile, była rola pośrednika, jaka odgrywali wspólni sprzymierzeńcy na Zachodzie. Nie tylko międzynarodowe konfederacje związków zawodowych, ale także pozarządowe organizacje, jak Amnesty International, potępiały łamanie praw człowieka w Polsce i Chile oraz ustalały spotkania z reprezentantami opozycji chilijskiej i polskiej na forach międzynarodowych ${ }^{42}$. Papież Jan Paweł II również zestawił te dwa przypadki. Podczas swojej wizyty w Chile w kwietniu 1987 r. zignorował oficjalny program i spotkał się z liderami opozycji politycznej i reprezentantami wszystkich związków zawodowych ${ }^{43}$.

Wszystkie te fakty dowodza, że Solidarność i chilijski opozycyjny ruch związkowy przez całe lata osiemdziesiąte utrzymywały regularne kontakty.

39 S.A. Oushakine, The Terrifying Mimicry of Samizdat, „Public Culture” 2001, vol. 13, no. 2, s. 191-214.

${ }^{40}$ Wczesne przykłady: Archiwum Akt Nowych (dalej: AAN), KC PZPR, LXXVI-531, Notatka. Udział Polski w międzynarodowej solidarności z Chile, Warszawa, 17 IX 1974; IPN Ld, pf 13/408, t. I, Chilijscy uchodźcy polityczni w Polsce, Warszawa 1974, s. 24-24v. Chcielibyśmy wyrazić naszą wdzięczność Przemysławowi Gasztold-Seniowi za wskazanie nam tych dokumentów.

${ }^{41}$ P. Kornbluh, The Pinochet File. A Declassified Dossier on Atrocity and Accountability, New York 2013.

${ }^{42}$ R. Brier, op. cit.

${ }^{43}$ T. Konopka, Chile i Polska..., s. 62-63. 
Michnik, Wałęsa, Milewski oraz inni polscy działacze opozycyjni wielokrotnie ogłaszali deklaracje solidarności z chilijskimi kolegami. Plany Wałęsy, żeby złożyć wizytę w Chile, zostały jednak powstrzymane przez rząd chilijski, który był świadomy wpływu, jaki taka wizyta mogła wywrzeć na wzrost nastrojów opozycyjnych. W 1988 r. reżim Pinocheta wysłał rektora Polskiej Misji Katolickiej w Chile, Brunona Rychlowskiego, z tajna misja do Polski, żeby we współpracy z polskim Kościołem zablokować wizytę Wałęsy w Chile ${ }^{44}$. Następnego roku rząd nawet zwolnił z więzienia dwóch liderów związkowych: chrześcijańskiego demokratę Manuela Bustosa i socjaldemokratę Artura Martíneza, pod warunkiem jednak, że wizyta Wałęsy w Chile w październiku 1989 r. zostanie odwołana ${ }^{45}$. Fakt ten szeroko celebrowano jako symbol potęgi ponadnarodowej solidarności i wspólnego protestu ${ }^{46}$.

\section{RPA: kłopoty z oporem wobec apartheidu}

Jeszcze bardziej niż Nikaragua i Chile opinię publiczna na całym świecie, mobilizowała RPA. Zdaniem prof. Jana Aarta Scholtego z Uniwersytetu Warwick „opór wobec apartheidu był jednym z największych, najbardziej trwałych i prawdopodobnie najbardziej wpływowych ruchów społecznych w końcu dwudziestego wieku" ${ }^{47}$. Agresywny system segregacji w RPA od momentu powstania w 1948 r. spotkał się z opozycją afrykańskich działaczy i międzynarodowych ruchów dekolonizacyjnych, ale nie był traktowany priorytetowo w Europie Zachodniej. Masakra w Sharpeville w marcu 1960 r. spowodowała gwałtowny wzrost ponadnarodowej aktywności w Europie Zachodniej i Wschodniej, ale aresztowanie liderów Afrykańskiego Kongresu Narodowego (African National Congress - ANC), międzynarodowa izolacja RPA i wzrost znaczenia innych spraw, jak Wietnam, odsunęły RPA na dalszy plan. Ruch przeciwko apartheidowi ożył dopiero po powstaniu w Soweto w czerwcu 1976 r. i zamieszkach na tle politycznym, jakie wybuchały po jego stłumieniu. W latach osiemdziesiatych międzynarodowy protest przeciwko apartheidowi wszedł na nowy poziom. Lokalne organizacje zaczęły współpracować i stały się instytucjami o zasięgu narodowym. Organizowały ponadnarodowe kampanie i lobbowały na rzecz wprowadzenia embarg i bojkotów. Równocześnie

${ }^{44}$ El contacto polaco del Papa en Chile, „El Mercurio”, 10 IV 2005. Na temat Rychlowskiego zob. np.: R. Olivares, Juventud y enseñanza de la Filosofía en Bruno Rychlowski, „La Cañada" 2013, nro. 4, s. 53-66.

45 „New York Times”, 25 X 1989.

46 J.P. Marthoz, Bustos et Martinez sont libres: merci Watęa, „Le Soir”, 25 X 1989, s. 4.

${ }^{47}$ J.A. Scholte, Anti-Apartheid and the Emergence of a Global Civil Society, „Acta Sociologica” 2007, vol. L, no. 3, s. 34. Ogólne wprowadzenie: W. Goedertier, The Quest for Transnational Authority, the Anti-Apartheid Movements of the European Community, „Revue Belge de Philologie et d'Histoire" 2011, no. 3-4, s. 1249-1276. 
przyciagały ogromną uwagę opinii publicznej, czego znakomitym przykładem były utwory z muzyki popularnej, jak Biko Petera Gabriela (1980), Free Nelson Mandela The Specials AKA (1984), Gimme hope Jo'anna Eddy Granta (1988) i światowe koncerty, jak hołd dla Nelsona Mandeli w jego 70. urodziny na stadionie Wembley w Londynie w 1988 r.

Solidarność nie mogła tego oczywiście zignorować. Istniały nawet wyraźne podobieństwa pomiędzy dwoma najbardziej głośnymi sprawami lat osiemdziesiątych. Lech Wałęsa otrzymał Pokojową Nagrodę Nobla w 1983 r., a czarnoskóry biskup z RPA, Desmond Tutu rok później. W listopadzie 1984 r. Polska ogłosiła, że opuszcza MOP po tym, jak organizacja ta opublikowała raport krytykujacy jej stosunek do Solidarności. RPA zrobiła to samo: formalnie wycofała się z MOP w 1963 r. w odpowiedzi na zarzuty dotyczące łamania praw związkowych ${ }^{48}$. Kiedy rząd Bothy wzmógł represje w latach osiemdziesiątych, obserwatorzy zachodni często wskazywali na podobieństwa pomiędzy Polską a RPA i dostrzegali w reorganizacji ruchów związkowych RPA „nowa Solidarność”, powstajaca jako reakcja na przemoc państwa ${ }^{49}$. Reprezentanci Biura Koordynacyjnego NSZZ „Solidarność” za Granicą i południowoafrykańskiej opozycji związkowej regularnie spotykali się na forach międzynarodowych i konferencjach w Europie Zachodniej, organizowanych przez wspólnych sojuszników, jak MKWZZ i ŚKP. Podobnie działo się na uroczystościach o lokalnej skali. Tadeusz Konopka, przedstawiciel Solidarności we Włoszech ${ }^{50}$, wspominał, jak często zapraszano go na wydarzenia razem z działaczami $\mathrm{ANC}^{51}$.

Nie był to zatem zbieg okoliczności, że starano się łączyć oba ruchy po zwycięstwach 1989 r. Dwóch honorowych gości uczestniczyło w 77. Sesji Ogólnej MOP w czerwcu 1990 r.: Tadeusz Mazowiecki - polski premier od września 1989 r. i pierwszy niekomunistyczny przywódca w bloku wschodnim oraz Nelson Mandela - wypuszczony z więzienia w lutym 1990 r. Ich obecność „symbolizowała wspólne osiagnięcia MOP”52. W 1990 r. byli polscy dysydenci, jak Michnik, zaangażowali się również w pracę Komisji Prawdy i Pojednania (Truth and Reconciliation Commission - TRC) ${ }^{53}$. Nawet muzyka pop łączyła

${ }^{48}$ I. Goddeeris, The limits of lobbying: ILO and Solidarność, w: ILO Histories. Essays on the International Labour Organization and its Impact on the World during the Twentieth Century, ed. J. Van Daele, M. Rodríguez García, G. Van Goethem, M. van der Linden, Bern 2010, s. 437.

49 „Socialistisk Arbejderavis”, VI 1985, nr. 10, s. 8.

${ }^{50}$ I. Goddeeris, Ministerstwo Spraw Zagranicznych..., cz. 2, s. 318-319, 327, 336.

51 Wywiad z Tadeuszem Konopka, przeprowadzony przez Idesbalda Goddeerisa, Warszawa, 2 II 2015.

52 „Solidarność News”, VII 1990, s. 154. W 1981 r. Bronisław Geremek, jeden z najsławniejszych doradców Solidarności, również brał udział w komisji MOP przeciwko apartheidowi. Zob. IPN, BU 01820/49, t. XI, Pismo Jerzego Milewskiego do TKK, Bruksela, 15 VII 1983, s. 231-240.

${ }^{3}$ Dealing with the Past. Truth and reconciliation in South Africa, ed. A. Boraine, J. Levy, R. Scheffer, Rondebosch 1994; F. du Bois, A. du Bois-Pedain, Post-Conflict Justice and the 
Solidarność i opór wobec apartheidu. W grudniu 1989 r., w pierwszą rocznicę ogłoszenia stanu wojennego obchodzona w demokratycznej Polsce, w Stoczni Gdańskiej odbył się koncert reggae przeciwko apartheidowi. Analogia do koncertu na Wembley jest oczywista, chociaż muzyków w Gdańsku wystapiło znacznie mniej54. Jeden z wykonawców, urodzony na Jamajce i mieszkający w Wielkiej Brytanii poeta Linton Kwesi Johnson, w 1991 r. napisał piosenkę Mi Revalueshanary Fren, poświęconą wspólnym związkom rewolucyjnym $\mathrm{z}$ Europy Wschodniej i walce $\mathrm{z}$ apartheidem ${ }^{55}$.

Wydaje się jednak, że pamięć zbiorowa albo niezbyt właściwie łączy Solidarność i opór wobec apartheidu, albo przynajmniej wyolbrzymia prawdziwy zakres ich współpracy. Tak jak w przypadku Chile i Nikaragui, pewne części opozycji południowoafrykańskiej, a szczególnie ruch związkowy, chętnie podkreślały podobieństwa z Solidarnościa. Na przykład Federacja Południowoafrykańskich Związków Zawodowych (Federation of South African Trade Unions - FOSATU) porównała siebie do polskiego niezależnego związku zawodowego, żeby skrytykować porozumienie pomiędzy ANC i Południowoafrykańską Partią Komunistyczna (South African Communist Party - SACP) ${ }^{56}$. W gruncie rzeczy jednak opozycja w RPA była wysoce sceptyczna w stosunku do Solidarności. Ta również niezbyt interesowała się współpracą ${ }^{57}$. Przez lata osiemdziesiąte Biuro Koordynacyjne NSZZ „Solidarność” za Granica tylko okazjonalnie wydawało deklaracje sympatii dla walki przeciwko apartheidowi. 16 VI 1986 r., w 10. rocznicę powstania w Soweto, Jerzy Milewski odczytał list od Lecha Wałęsy do Grupy Robotniczej MOP na 72. Sesji Ogólnej w Genewie ${ }^{58}$. Prezydent Biura Koordynacyjnego zanim to uczynił, powiedział, że „jesteśmy głęboko dotknięci rozwojem sytuacji w Południowej Afryce”, wyraził swoją „najsilniejszą solidarność z większością czarnoskórych robotników Południowej Afryki” i słowa otuchy dla Kongresu Południowoafrykańskich

Reconciliatory Paradigm: the South African Experience in Context, w: Justice and Reconciliation in Post-Apartheid South Africa, ed. F. du Bois, A. du Bois-Pedain, Cambridge 2009, s. 297; 1989 in a Global Perspective, ed. U. Engel, F. Hadler, M. Middell, Leipzig 2015, z prezentacja Chrisa Saundersa o RPA.

${ }^{54}$ Dane zostały upublicznione następnego roku: http://www.discogs.com/Various-Solidarno\%C5\%9B\%C4\%87-Anti-Apartheid-13121989-Gda\%C5\%84sk-Shipyard-Hall/release/2156251 (dostęp: 4 VII 2018).

55 Zob. https://www.youtube.com/watch?v=lzpaomcpxiE. Utwór pojawił się na jego albumie Tings an’ Times. Co ciekawe, w refrenie wymienia Węgra Jánosa Kádára, Bułgara Todora Żiwkowa, Czechosłowaka Gustáva Husáka, Niemca Wschodniego Ericha Honeckera i Rumuna Nicolae Ceauşescu, ale milczy o Wojciechu Jaruzelskim i Lechu Wałęsie, co więcej, za obalenie żelaznej kurtyny chwali raczej Węgry niż Polskę, śpiewając „from Hungary to Poelan to Romania". Słowa piosenki zob. http://www.metrolyrics.com/mi-revalueshanary-fren-lyrics-linton-kwesi-johnson.html (dostęp: 4 VII 2018).

${ }^{56}$ Black History and the Class Struggle. A Spartacist Pamphlet, New York 1995, s. 14.

57 V. Shubin, M. Traikova, There is no threat from the Eastern Bloc, w: The Road to Democracy in South Africa, vol. III: International Solidarity, Part 2, Pretoria 2008, s. 985-1066.

58 „Solidarność News”, 30 VI 1986, no. 71. 
Związków Zawodowych (Congress of South African Trade Unions - COSATU) i Rady Południowoafrykańskich Związków Zawodowych (Council of Unions of South Africa - CUSA), których liderzy przebywali w więzieniu. Milewski przyrównał RPA do własnego kraju, a stan wyjątkowy w RPA po 1985 r. do sytuacji w Polsce, gdzie stan wojenny skończył się co prawda formalnie trzy lata wcześniej, ale w praktyce - jak twierdził - był kontynuowany, ponieważ wciąż obowiązywał zakaz działalności Solidarności, a 300 związkowców nadal przebywało w więzieniu. Następnie przeczytał list od Wałęsy. Co ciekawe, przywódca Solidarności nie odniósł się do sytuacji w RPA, a jedynie przypomniał zebranym o stosowanych represjach w Polsce. Ponadto oświadczenie to było jego jedyna publiczna deklaracją solidarności z ruchem przeciwko apartheidowi pomiędzy 1984 i 1989 r. To nie tylko pokazuje duży kontrast między Polska i Chile, ale także budzi zdziwienie w przypadku uświadomienia sobie światowego zainteresowania zarówno Polska, jak i RPA w latach osiemdziesiątych.

$\mathrm{Na}$ ten brak wspólnego działania złożyło się kilka powodów. Jeden już wyjaśniono powyżej - była to rywalizacja z komunistami. Warszawa także sympatyzowała $\mathrm{z}$ ruchem przeciwko apartheidowi. Te kontakty nie były co prawda jak dotąd przedmiotem badań naukowych, ale widać je wyraźnie $\mathrm{w}$ niektórych niedawno ujawnionych dokumentach $\mathrm{w}$ archiwach polskiego Ministerstwa Spraw Zagranicznych. W marcu 1982 r. kilku polskich wojewodów i burmistrzów podpisało petycję zainicjowana przez burmistrza Glasgow, by uwolnić przywódce ANC Nelsona Mandelę 59 . We wrześniu 1983 r. sekretarz generalny SACP Moses Mabhida odwiedził Polskę ${ }^{60}$. W kwietniu 1985 r. dyplomaci z Polski i innych krajów Europy Wschodniej spotkali się w radzieckiej ambasadzie w Londynie z Murphym Morobem, jednym z założycieli Zjednoczonego Frontu Demokratycznego (United Democratic Front UDF), ważnej organizacji przeciw apartheidowi, która zwołała w brytyjskiej stolicy kongres $\mathrm{w}$ tamtym czasie ${ }^{61}$. Wszystkie te kontakty pokazuja, że rząd w Warszawie sprzymierzał się z opozycją RPA. To utrudniało identyfikowanie oraz współpracę Solidarności z ruchem przeciwko apartheidowi ${ }^{62}$.

Dodatkowo istniała jeszcze szczególna przyczyna kłopotliwych stosunków między dwoma masowymi ruchami: władze południowoafrykańskie przyjmowały polskich uchodźców i to spotykało się z nieprzychylną reakcją opozycji afrykańskiej. Polski kryzys lat 1980-1981 wiązał się z exodusem uchodźców ${ }^{63}$.

\footnotetext{
${ }^{59}$ MSZ, Z26/85, W5, RPA 1982, Pismo od Polskiego Komitetu Solidarność z Narodami Azji i Afryki, 18 III 1982.

${ }^{60} \mathrm{MSZ}, \mathrm{Z34} / 86$, W3, Notatka z 22 IX 1983.

${ }^{61}$ MSZ, Z18/88, W5, Notatka z 19 IV 1985.

${ }^{62}$ H. Adam, K. Moodley, The Opening of the Apartheid Mind. Options for the New South Africa, Berkeley 1993, s. 83.

${ }^{63}$ D. Stola, Kraj bez wyjścia? Migracje z Polski 1949-1989, Warszawa 2010, s. 303 i n.; Pro-Solidarity Initiatives of the Polish Diaspora and Polish Migrants in the Western world (1980-1989), red. P. Pleskot, Warszawa 2018 (w druku).
} 
Ponad 20 tys. z nich udało się do sasiedniej Austrii, gdzie starali się o przyznanie azylu politycznego i przebywali w obozach dla uchodźców ${ }^{64}$. Ponieważ wielu posiadało wysokie wykształcenie techniczne, było w młodym wieku i sprzeciwiało się komunizmowi, w RPA chętnie zatrudniano ich w przemyśle. Od $1981 \mathrm{r}$. rozpoczęto nawet specjalny program z tym związany. Ambasada RPA w Wiedniu zatrudniła trzech pracowników pochodzenia polskiego i dodatkowych dziesięciu, którzy mówili po polsku, żeby znaleźć kandydatów do pracy w RPA. Rząd RPA także otworzył kolejne siedem biur rekrutujących w całej Europie, ale chyba nie były aż tak aktywne. Dodatkowo liczne firmy - m.in. południowoafrykańskie publiczne przedsiębiorstwo dostarczajace prąd Escom, częściowo państwowa huta Iscor, mieszczące się w Johannesburgu energetyczne i chemiczne przedsiębiorstwo Sasol oraz międzynarodowe firmy General Mining i Volkswagen - wysłały swoich agentów do Austrii. W rezultacie spora liczba Polaków podpisała kontrakty i przeprowadziła się do RPA. W styczniu 1982 r. ok. 200 Polaków ruszyło w podróż. Według źródeł południowoafrykańskich w kwietniu 1982 r. już ok. 150 Polaków składało dokumenty codziennie $\mathrm{w}$ południowoafrykańskiej ambasadzie w Wiedniu. W sumie w 1982 r. ok. 6 tys. polskich obywateli przeprowadziło się z Austrii do RPA ${ }^{65}$. Większość tych nowych imigrantów osiedliła się w regionach przemysłowych, ale Organizacja Ludu Afryki Południowo-Zachodniej (South West Africa People's Organization - SWAPO) twierdziła, że niektórzy wstapili do armii południowoafrykańskiej i walczyli w wojnie przeciwko namibijskim bojownikom niepodległościowym ${ }^{66}$.

Sprowadzanie polskich imigrantów do RPA nie było oczywiste w tamtych czasach. RPA była izolowana w świecie i stanowiła przedmiot wielu rezolucji ONZ dotyczacych ograniczania ekonomicznych i innych kontaktów tak długo, dopóki apartheid istniał. Imigracja nowych białych osadników również wzmacniała pozycję białych, szczególnie w sytuacji, w której rosnąca liczba białych Południowoafrykańczyków emigrowała z kraju z powodu przemocy. Rekrutacja spotkała się więc z ostrą krytyką z różnych stron. ANC wyraził swoje zaniepokojenie już w 1982 r. Polskie władze w Warszawie regularnie dystansowały się od rekrutacji, podkreślając, że miały one miejsce poza terytorium Polski i poza ich kontrolą ${ }^{67}$.

${ }^{64}$ O. Rathkolb, Austria: An Ambivalent Attitude of Trade Unions and Political Parties, w: Solidarity with Solidarity. Western European Trade Unions and the Polish Crisis, 1980-1982, ed. I. Goddeeris, Lanham 2013, s. 279.

${ }_{65}$ Tylko od 3500 do 4000. Zob. A. Żukowski, Republika Południowej Afryki, w: Akcja niepodległościowa na terenie międzynarodowym 1945-1990, red. T. Piesakowski, Londyn 1999, s. $637-638$.

${ }^{66}$ MSZ, Z26/85, W5, Notatka nt. niektórych aspektów sytuacji wewnętrznej w RPA w okresie październik 1981 r., IV 1982, s. 11; MSZ, Z27/86, W3, Notatka z 29 I 1982; MSZ, Z35/86, W5, Notatka informacyjna dot. Polaków w Republice Południowej Afryki, 13 IX 1983, s. 6.

${ }^{67}$ MSZ, Z27/86, W3, Notatki z 29 I oraz 4 II 1982. 
Najbardziej obszerną krytykę można było znaleźć w „liście do polskich katolików od Kościoła Południowej Afryki”. W tej publikacji, liczacej osiem stron i wydanej przez południowoafrykańską Konferencję Episkopatu w październiku 1982 r..$^{68}$, podkreślono okrucieństwo reżimu RPA. Episkopat wyraził swoją sympatię dla Solidarności i nawiązał do polskiej sytuacji poprzez odniesienie do „niedawnego traktowania niektórych związków zawodowych [...] z podobnymi celami do Solidarności” i „zjawiska w każdym totalitarnym państwie”. Jednak przestrzegł przed różnymi pułapkami, w które można było łatwo wpaść, jak wyższy standard życia, przywileje dla białych, wrażenie, że RPA to pod każdym względem normalny kraj, a przede wszystkim brak zrozumienia postaw czarnoskórych i przyjmowanie dominującej perspektywy białych.

Cała sprawa rekrutacji uchodźców postawiła Solidarność w niezręcznej sytuacji. Jej członkowie i sympatycy, którzy imigrowali do RPA, teraz służyli szeroko potępianemu reżimowi. Byli sojusznicy, tak jak południowoafrykańscy biskupi, stali się krytyczni wobec opozycji w Polsce. Reżim komunistyczny mógł otwarcie i wprost poprzeć podziwiany na świecie ruch przeciwko apartheidowi. Pod naciskiem przywództwa ŚKP, które przekonywało Milewskiego, że to „nieszczęśliwe, że w momencie kiedy Solidarność wezwała solidarność całego świata, sama nie pokazuje solidarności z innymi poddanymi represjom ludami”, Biuro Koordynacyjne zrozumiało ważność tej sprawy dla swojej pozycji międzynarodowej69. W kwietniu 1983 r., pół roku po liście biskupów z RPA, Milewski pojechał do Kenii, Zambii i Zimbabwe. W ostatnim kraju 18 IV 1983 r. wygłosił przemówienie, które potem zostało upublicznione różnymi kanałami. Milewski starał się łączyć ideologicznie Solidarność i ruch przeciwko apartheidowi przez używanie argumentów podobnych do tych, które odnosiły się do Ameryki Łacińskiej: „Solidarność wyraża swoją pełna solidarność z czarnoskórą większością robotników Południowej Afryki i ich niezależnego związku zawodowego, który - tak jak Solidarność - tworzy związek zawodowy i oddolny ruch społeczny walczacy o poszanowanie praw związkowych, podstawowych praw człowieka i demokratycznych wolności dla społeczeństwa". Także niejednoznacznie wyraził swoją krytykę południowoafrykańskich kampanii rekrutacyjnych, które - jak przyznał - były forma aprobaty apartheidu. Podkreślił, że już podjął pewne działania, żeby się im przeciwstawić. Jego Biuro skontaktowało się z Austriacką Federacją Związków Zawodowych (Österreichischer Gewerkschaftsbund - ÖGB), „żeby przeprowadzić kampanię informacyjną wśród polskich uchodźców, pokazująca

${ }^{68}$ IISH, Solidarność Nederland, 6, South Africa. The case against immigration. A letter to Polish Catholics from the Church in South Africa. List jest również wspomniany (i datowany) w: MSZ, Z35/86, Notatka informacyjna dot. Polaków w Republice Południowej Afryki, 13 IX 1983, s. 6.

${ }^{69}$ KADOC, WCL, 326, Pismo od Jana Kułakowskiego do Jerzego Milewskiego, 9 XI 1982. 
prawdziwą naturę apartheidu i fakt, że emigracja do RPA jest równoznaczna z odmowa zarobków dla czarnoskórych pracowników"70.

W dwóch listach do przywódców polskiego podziemia, które zostały przemycone do Polski, ale przechwycone przez polskie służby specjalne, Milewski dał wyraz swojej satysfakcji: „Moja inicjatywa afrykańska rozwija się doskonale". Był przekonany, że wywarł dobre wrażenie, zarówno na związkowcach w Zimbabwe, Zambii i Kenii, jak i na ONZ, MOP i innych organizacjach międzynarodowych. Na odbywającej się co cztery lata konferencji MKWZZ w Oslo w lipcu 1983 r. liczni delegaci z Afryki nosili plakietki Solidarności. Milewski oczekiwał teraz ostrej reakcji ze strony obozu czerwonych: uważał komunizm w Afryce za tak poważna groźbę, że antykomunizm stanowił dla niego druga motywację - wraz z presją międzynarodowa - w afrykańskiej kampanii. Napisał, że był poruszony popularnością komunizmu w takich krajach, jak Angola, Mozambik i Etiopia i obawiał się, że RPA stanie się komunistyczna, jeśli apartheidu nie zastapi demokracja. Zauważył również, że Organizacja Afrykańskiej Jedności Związkowej (Organization of African Trade Union Unity - OATUU) była infiltrowana przez komunistów i finansowana przez Libię. Poparcie wyrażone przez niezależne afrykańskie związki zawodowe dla Solidarności osłabiłoby afrykański komunizm.

Milewski żałował jedynie, że to jego Biuro Koordynacyjne, a nie przywódcy Tymczasowej Komisji Koordynacyjnej (TKK), było autorem przesłania. Dlatego też ponaglił Wałęsę, Bogdana Lisa i swoich innych współpracowników w Polsce, żeby napisali rezolucję, która potępiałaby apartheid jako system równie obrzydliwy jak komunizm. Jego zdaniem Solidarność była jedynym związkiem zawodowym w świecie, który jeszcze nie potępił reżimu w RPA. Taka rezolucja spotkałaby się z wielką sympatię afrykańskich związków zawodowych oraz rządów dla Solidarności i otworzyłaby drzwi do reszty świata. Mogłaby zmienić postawę indyjskiej premier Indiry Gandhi, która do tej pory nie poparła Solidarności. Natomiast zmiana jej opinii być może wpłynęłaby na niektóre państwa arabskie i wreszcie na Chiny. W ten sposób Rada Bezpieczeństwa ONZ mogłaby stać się następnym forum działania. Milewski nie ograniczał się w swoich ambicjach i w oczywisty sposób miał nadzieję użyć RPA jako pierwszego kroku w globalnym działaniu ${ }^{71}$.

Sprawy jednakże nie potoczyły się zgodnie z oczekiwaniami. Wręcz przeciwnie, jego inicjatywa została zatrzymana w samej RPA. Wystapienie Milewskiego w Zimbabwe wywołało sporo niezadowolenia wśród jego rodaków w RPA. Szczególnie starsza polska wspólnota, która osiedliła się tam podczas i tuż po zakończeniu II wojny światowej i potem była poszerzana o Polaków opuszczających inne kraje afrykańskie w trakcie fali dekolonizacji w latach

\footnotetext{
70 „Solidarność News”, 10 VI 1983, no. 1; IISH, Solidarność Nederland, 75.

${ }^{71}$ IPN, BU 01820/49, t. XI, Pismo Jerzego Milewskiego do TKK, Bruksela, 7 V 1983, s. 227-230; ibidem, Pismo Jerzego Milewskiego do TKK, Bruksela, 15 VII 1983, s. 231-240.
} 
sześćdziesiątych, sprzeciwiała się jego krytyce kampanii rekrutacyjnych ${ }^{72}$. Podobną opinię wyrażali także niektórzy nowo przybyli imigranci, którzy byli otwarci na rasistowski i antykomunistyczny dyskurs białej elity. Słynny stał się Janusz Waluś, który imigrował do RPA w 1981 r., wstapił do skrajnie prawicowych organizacji i w 1993 r. zamordował przywódcę SACP Chrisa Haniego ${ }^{73}$.

W czerwcu 1983 r. prezydent Rady Polskiej Diaspory w RPA Edward de Virion opublikował list otwarty, który ukazał się w różnych ważnych periodykach wydawanych w polskich migracyjnych kręgach, takich jak „Kultura” i „Słowo”. Zarzucał Milewskiemu, że podzielał opinię episkopatu RPA, który wspierał komunizm, ale nie zauważał, że Zwiąek Radziecki przygotowywał „wyzwolenie” RPA. Odpierał zarzuty, jakoby Polacy odbierali prace czarnoskórym robotnikom, ponieważ to była praca dla dobrze wykształconych inżynierów. De Virion przewidywał, że konsekwencje tej sytuacji mogłyby być wręcz odwrotne, jako że zatrudnienie Polaków przyczyniłoby się do powstania nowych miejsc pracy dla czarnoskórych. Żałował również, że Milewski wygłosił swoją mowę w Zimbabwe, czyli w „państwie, które znajduje się na równi pochyłej w drodze do przekształcenia zachodniej demokracji parlamentarnej w kraj wzorowany na modelu kremlowskim, gdzie klika rządząca, na podobnych zasadach jak reżym warszawski, przemoca odbiera prawa i aspiracje mieszkańców ziemi Matabele" - co było odniesieniem do masakr Gukurahundi i w Matabeleland w latach 1982-1985 ${ }^{74}$.

Redakcja „Kultury” dodała do listu post scriptum, oświadczając, że otrzymała wielką liczbę listów z RPA, także od reprezentantów nowej imigracji, ostro protestujacych przeciwko wystapieniu Milewskiego. Ich reakcja nie przeszła bez echa. Sprawiła, że przesłanie Milewskiego zostało osłabione i w gruncie rzeczy pogrzebało całą afrykańską inicjatywę. Po lecie 1983 r. apartheid przestał być dla Solidarności kluczową sprawa. Milewski czasami wspominał, że apartheid był popierany przez czarne związki zawodowe w RPA, ale nikt nie zwracał na to uwagi ${ }^{75}$. Dopiero w czerwcu 1986 r., w 10. rocznicę powstania w Soweto, Jerzy Milewski odczytał list od Lecha Wałęsy na sesji MOP. Nie wywarł tym jednak wielkiego wrażenia. Podział w obrębie antykomunistycznej diaspory polskiej wraz z zaangażowaniem Warszawy przeciwko apartheidowi złożyły się na dramatycznie niskie zaangażowanie Solidarności w sprawę RPA.

${ }^{72} \mathrm{Na}$ temat jego oficjalnego stanowiska do apartheidu zob. A. Żukowski, op. cit., s. 635.

${ }^{73}$ M. Evans, Broadcasting the End of Apartheid. Live Television and the Birth of the New South Africa, London-New York 2014, s. 148-150.

74 „Kultura” 1983, nr 6 (429), s. 170-171 oraz kopia „Słowa” w IISH, Solidarność Nederland, 75. Więcej na temat „starej” polskiej wspólnoty w RPA, Rady Polonii w Afryce Południowej, a także jej podobnie krytycznej reakcji na list episkopatu, zob. MSZ, Z35/86, W5, Notatka informacyjna dot. Polaków w Republice Południowej Afryki, 13 IX 1983, szczególnie s. 4.

75 Zob. np. krótką uwagę podczas wywiadu w Radio Wolna Europa 6 II 1985 r.: IPN, BU 01820/49, t. IV, s. 111 i n. 


\section{Konkluzje}

Od samego powstania Solidarności w latach osiemdziesiątych jej relacje z innymi ruchami opozycyjnymi i oporem obywatelskim w Trzecim Świecie były naznaczone kontrowersjami i niejednoznacznością. Z jednej strony walka Solidarności nieraz łączyła się ze sprawami na globalnym Południu w wymiarach realnym i symbolicznym. W swoim przemówieniu z okazji wręczenia Pokojowej Nagrody Nobla, przeczytanym przez Bohdana Cywińskiego w grudniu 1983 r., Lech Wałęsa otwarcie stwierdził, że kryzys w Polsce nie odnosił się tylko do relacji pomiędzy Wschodem a Zachodem, ale również do tych pomiędzy Północa i Południem ${ }^{76}$. Przykładami tego były obecność chilijskiego związkowca Rodolfa Seguela i podróże przedstawicieli Solidarności po całym świecie. W 1986 r. Bohdan Cywiński wraz z anonimowym działaczem Solidarności z Polski deklarowali w wywiadzie z Janem Kułakowskim i benińskim działaczem związkowym Dominique Aguessy swoja głęboką sympatię dla związkowców z Afryki i Ameryki Łacińskiej, których otwartość i całościowa wizję ruchu zwiąkowego zestawiali z bezbarwnymi i zbiurokratyzowanymi poglądami związkowców z Zachodu ${ }^{77}$. W listopadzie 1989 r. Wałęsa po raz pierwszy pojechał do Ameryki: nie tylko do Waszyngtonu, gdzie odbył prywatna rozmowę z Manuelem Bustosem, ale także do Caracas $^{78}$. W Wenezueli, która $z$ powodów długu i wprowadzanych reform znajdowała się wtedy w ekonomicznym, finansowym i społecznym kryzysie, wezwał do transformacji zarówno komunizmu, jak i kapitalizmu ${ }^{79}$.

Nie tylko Solidarność, ale również jej wielbiciele na Zachodzie kultywowali tę północno-południową więź. Kampanie poparcia dla Solidarności były w dużym stopniu inspirowane przez wzorce i idee z poprzednich kampanii prowadzonych na rzecz ruchów wyzwolenia narodowego i cywilnego oporu przeciwko dyktaturom na Południu ${ }^{80}$. Rozczarowani nieudanymi rewolucjami w Trzecim Świecie, aktywiści z kampanii przeciwko wojnie w Wietnamie i Pinochetowi w Chile w latach siedemdziesiątych stali się ikonami jedności z Solidarnością ${ }^{81}$.

${ }^{76}$ Wykład Lecha Wałęsy z 11 XII 1983 r. jest dostępny na stronie: http://www.nobelprize. org/nobel_prizes/peace/laureates/1983/walesa-lecture.html.

77 Solidarność i Trzeci Świat, „Widnokrag” 1986, nr 1, s. 25-36.

78 Wywiad z Anna Nitosławska, przeprowadzony na Skype przez Idesbalda Goddeerisa, Leuven-Ottawa, 4 VI 2015. Nitosławska była tłumaczem Wałęsy w Caracas, Waszyngtonie i Kanadzie.

${ }^{79}$ J.I. Urquijo, El movimiento obrero de Venezuela, Lima 2004, s. 52.

${ }^{80}$ G. Hart, For our Freedom and Yours. Za nasza $i$ wasza wolność, London 1995, s. 14; K. Christiaens, I. Goddeeris, W. Goedertier, Inspirées par le Sud? Les mobilisations transnationales Est-Ouest pendant la guerre froide, „Vingtième Siècle, Revue d'Histoire” 2011, no. 109 , s. $155-168$.

${ }^{81}$ R. Gildea, J. Mark, N. Pas, European Radicals and the 'Third World', „Cultural and Social History” 2011, vol. VIII, no. 4, s. 464-466; M. Scott Christofferson, French Intellectuals Against the Left. The Antitotalitarian Moment of the 1970s, New York 2004. 
Z drugiej strony sprawa relacji pomiędzy Północą i Południem rzuciła również cień na Solidarność i stała się nawet kluczowym punktem w jej rozwoju jako kontestowanego symbolu. Solidarność być może wywierała duży wpływ na współczesne jej ruchy społeczne i walki oporu obywatelskiego $\mathrm{w}$ wielu pozaeuropejskich regionach, ale jej historiografowie pozostaja mniej przekonani, a nawet sceptyczni co do odwzajemniania tego zainteresowania. Ostatnie wysiłki w celu upowszechnienia roli Solidarności i przedstawienia jej jako ogólnoświatowego symbolu na rzecz zmiany paradoksalnie i często bezpowrotnie przywróciły pytania i wattpliwości na temat zainteresowania tego związku zawodowego wydarzeniami poza granicami Polski lub bloku wschodniego. W gruncie rzeczy niewiele ruchów dysydenckich było w tym samym czasie tak zuniwersalizowanych i sprowincjonalizowanych, jak Solidarność. O ile jej przywództwo chętnie głosiło, że „prawa człowieka nie mają granic", a jej zwolennicy entuzjastycznie okrzyknęli polski związek zawodowy uniwersalnym symbolem „bycia jednościa z ludzkościa” ${ }^{2}$, to jednak było to $\mathrm{w}$ dużym stopniu strategicznym obronnym krokiem wymierzonym przeciwko krytykom, którzy opisywali Solidarność jako introwertyczne i prowincjonalne zjawisko. Wizja współczesnych krytyków Solidarności à la Chomsky, którzy utrzymuja, że polski niezależny związek zawodowy pozostał ograniczony jedynie do walki w kraju i przeciwstawiaja go rzekomo dużo bardziej zglobalizowanym rówieśnikom na Południu, odzwierciedla się również w wynikach badań, na podstawie których polski związek zawodowy uwidacznia się jako ruch, który raczej opieszale reagował na to, co się działo za granicą ${ }^{83}$. Taka interpretacja była zreszta obecna nawet w kręgach Solidarności. Tadeusz Konopka po powrocie z podróży do Ameryki Łacińskiej relacjonował: „Muszę się przyznać, że do tej pory zajmowanie się sprawami tak odległymi, jak np. problemy Ameryki Łacińskiej traktowałem jako ucieczkę od rzeczywistości. Nie pamiętam aby ktoś wpadł na pomysł organizowania w Polsce akcji na rzecz poparcia walki tam prowadzonej, może nawet w słusznym celu" ${ }^{4}$. Podobnie nawet sojusznicy Solidarności na Zachodzie byli zdziwieni nieinteresowaniem się przez nią walką z apartheidem i krytykowali brak jej międzynarodowej orientacji ${ }^{85}$.

W niniejszym artykule staraliśmy się odpowiedzieć na pytania odnoszące się do tego sceptycznego punktu widzenia na podstawie analizy stosunków nawiazywwanych przez Solidarność z Trzecim Światem. W sumie kontakty z ruchami społecznymi lub politycznymi w Trzecim Świecie miały raczej ograniczony charakter. Były podtrzymywane przez zaledwie kilku wiodących

\footnotetext{
${ }^{82}$ KADOC, WCL, 328, Dokumenty dotyczące konferencji na temat praw człowieka w Krakowie w sierpniu 1988 r.; ibidem, 327, Mowa Egila Aarvika w Oslo, 10 XII 1983.

${ }^{83}$ P. Kenney, op. cit., s. 68-71.

${ }_{84}$ T. Konopka, Uwagi po podróży..., s. 15.

${ }^{85}$ KADOC, WCL, 326, Pismo od Jana Kułakowskiego do Jerzego Milewskiego, 9 XI 1982.
} 
przedstawicieli i polegały na pośrednictwie swoich zachodnich sojuszników. Bledną one wszystkie w porównywaniu z intensywnością relacji we współpracy Solidarności z sojusznikami na Zachodzie. Poza tym były bardzo wybiórcze. Trzeba przyznać, że z różnych powodów, przede wszystkim zaś ze względu na strategię chadeckich sojuszników Solidarności, Ameryka Łacińska pojawiła się relatywnie szybko w obszarze jej zainteresowań. Natomiast znacznie mniej kontaktów istniało pomiędzy Biurem Koordynacyjnym NSZZ „Solidarność" za Granica i innymi regionami w Afryce i Azji. Ponadto Solidarność zaakceptowała tylko te sprawy, które posiadały instrumentalną wartość dla jej pozycji międzynarodowej. Na przykład niechętnie, i głównie pod presja zewnętrznych nacisków i okoliczności, uczestniczyła w walce przeciwko apartheidowi. W obawie o nadwyrężenie swojego profilu związkowego przez identyfikowanie z partiami politycznymi i ideologiami partnerów do współpracy szukała przede wszystkim wśród związków zawodowych ${ }^{86}$. Co równie ważne, starała się nie skupiać na otwarcie antykomunistycznych walkach. Wręcz przeciwnie, Solidarność nawet powstrzymywała się od bycia kojarzona ze sprawami wpisanymi w rywalizacje pomiędzy Wschodem i Zachodem. To stało się oczywiste nie tylko w jej niechęci do sprzymierzania się $\mathrm{z}$ antysandinistyczną opozycją w Nikaragui, ale także w jej stosunku do wojny Związku Radzieckiego w Afganistanie. Nawet pomimo że tacy jej sprzymierzeńcy, jak ŚKP i CLAT starali się zbliżyć opozycję polską i afganistańską i czasami łączyli Solidarność razem z reprezentantami afgańskiego oporu ${ }^{87}$, Biuro Koordynacyjne NSZZ „Solidarność” za Granicą nie wyraziło chęci większego zaangażowania $\mathrm{w}$ tej sprawie ${ }^{88}$. Podczas gdy inne polskie organizacje, jak Wolność i Pokój (WiP), otwarcie popierały afgański ruch oporu, zainteresowanie ze strony Solidarności było raczej nikłe. Afgańskiemu oporowi brakowało wymiaru związkowego i poparcie dla niego byłoby sprzeczne z wysiłkami zmierzajaccymi do wyjścia poza zimnowojenną dwubiegunowość.

Odpowiedzialność za niepowodzenia we współpracy z ruchami opozycyjnymi oraz oporu cywilnego w Trzecim Świecie nie powinna jednak obciążać wyłącznie Solidarności. Jeśli Solidarność dystansowała się wobec organizacji sprzeciwiających się apartheidowi i sandinistom, to odwrotna sytuacja była równie bliska prawdy, jako że opozycja w RPA i w Nikaragui z niechęcia odnosiła się do opozycji w Polsce. Podobnie było z ruchami na Zachodzie, które w owym czasie o wiele mniej się interesowały Solidarnościa, niż sugerują to uniwersalizujące narracje praw człowieka, przedstawiające te zdarzenia po

${ }^{86}$ Ibidem, Telegram od Jerzego Milewskiego, 26 X 1982; ibidem, wywiad z Jerzym Milewskim w „Labor”, 26 X 1982.

87 „Labor” $1983, \mathrm{n}^{\circ} 1$, s. 24.

88 Jedno z rzadkich odniesień Biura Koordynacyjnego NSZZ „Solidarność” za Granica do Afganistanu zob.: IPN, BU 01820/49, t. V, wywiady dla Głosu Ameryki, 13 XII 1985, i dla Radia Wolna Europa, 19 III 1985, s. 76 i n.; ibidem, t. XI, Pismo od Jerzego Milewskiego do TKK, Bruksela, 15 VII 1983, s. 231-240. Zob. też wstęp do tego artykułu. 
upadku socjalizmu państwowego. Z jednej strony dążenia Solidarności były sprzeczne z ich interesem uwolnienia dualizmu Północ-Południe od ciężaru rywalizacji zimnowojennej pomiędzy Wschodem i Zachodem, bo postrzegały ja jako europejski konflikt utrudniający w Trzecim Świecie postawę niezaangażowania i samostanowienia ${ }^{89}$. Z drugiej strony opozycja RPA i sandiniści utrzymywali dobre relacje z rządem polskim i otrzymywali wsparcie od wschodnioeuropejskich reżimów ${ }^{90}$.

Granice i odległości także utrudniały kontakt. Obok restrykcji nałożonych zarówno przez władze polskie, jak i rządy na Południu (reżim Pinocheta i sandinistów), odległość geograficzna i wysiłek związany z podróżami i komunikacją również odgrywały znacząca rolę. Kiedy w sierpniu 1988 r. Komisja Interwencji i Praworządności NSZZ „Solidarność” zorganizowała razem z WiP międzynarodowa konferencję w Krakowie na temat praw człowieka ${ }^{91}$, rozesłane zaproszenia przyjęte zostały w większości przez delegacje z Europy Zachodniej. Zaproszeni z Trzeciego Świata odmówili przyjazdu z powodu problemów wizowych, kwestii finansowych i innych trudności związanych z podróżą ${ }^{92}$.

W konfrontacji z tymi przeszkodami wyróżnia się rola pośredniczących partnerów. W gruncie rzeczy wszystkie przedsięwzięcia i podróże Solidarności na globalnym Południu zależały głównie od pieniędzy jej sprzymierzeńców na Zachodzie. Mieli oni dobrą wolę, ale równocześnie starali się nadać międzynarodowym kontaktom taki kształt, który odpowiadałby ich własnym zamierzeniom. Nic dziwnego zatem, że to właśnie zachodnioeuropejskie organizacje i lokalizacje, jak Bruksela, Rzym czy Genewa, były kluczowymi miejscami, w których Solidarność nabierała wymiaru światowego. Rezultaty tych działań miały jednak bardziej wyobrażony niż realny charakter.

\section{Streszczenie}

Kryzys w Polsce lat osiemdziesiątych nie wydarzył się w izolacji. Mniej więcej w tym samym czasie, jak w Polsce i innych krajach Europy Wschodniej, w wielu krajach Południa rósł obywatelski opór wobec autorytarnych rządów, zarówno prawicowych, jak i lewicowych. $\mathrm{W}$ niniejszym artykule zostały przeanalizowane powiązania Solidarności w prawdziwych

${ }^{89}$ K. Christiaens, I. Goddeeris, Beyond Western European Idealism: A Comparative Perspective on the Transnational Scope of Belgian Solidarity Movements with Nicaragua, Poland and South Africa in the 1980s, „Journal of Contemporary History”, 6 II 2015.

${ }^{90}$ K. Christiaens, Globalizing Nicaragua? An Entangled History of Sandinista Solidarity Campaigns in Western Europe, w: Making Sense of the Americas. How Protest Related to America in the 1980s and Beyond, ed. J. Hansen, C. Helm, F. Reichherzer, FrankfurtChicago 2015, s. 155-177.

${ }^{91}$ J. Laber, The Courage of Strangers. Coming of Age with the Human Rights Movement, New York 2002, s. 296-297.

${ }^{92}$ KADOC, WCL, 327, Organization of Human Rights International Conference, Kraków 1988; ibidem, Pismo od Jerzego Milewskiego do Jana Kułakowskiego, 24 V 1988. 
i wyobrażonych kategoriach z innymi międzynarodowymi sprawami i ruchami społecznymi w latach osiemdziesiątych. Druga, a zarazem ostatnia część koncentruje się na sieciach powiązań Biura Koordynacyjnego NSZZ „Solidarność” za Granica od 1982 r. i ilustruje niejednoznaczną reakcję Solidarności na wojnę przeciwko Contras w Nikaragui, dyktaturę Pinocheta w Chile i walkę $\mathrm{z}$ apartheidem $\mathrm{w}$ RPA. W ten sposób prezentujemy stosunek Solidarności do trzech causes célèbres, które zdominowały międzynarodowy obieg informacji i sprowokowały liczne kampanie społeczne toczące się równolegle do polskiego kryzysu.

W sumie kontakty z ruchami społecznymi lub politycznymi w Trzecim Świecie miały raczej ograniczony charakter. Były podtrzymywane przez zaledwie kilku głównych przedstawicieli i polegały na pośredniczeniu swoich zachodnich sojuszników. Bledną one w porównaniu z intensywnością relacji we współpracy Solidarności z sojusznikami na Zachodzie. Poza tym były bardzo wybiórcze. Solidarność zaakceptowała tylko te sprawy, które posiadały instrumentalną wartość dla jej pozycji międzynarodowej. Niechętnie, i głównie pod presja zewnętrznych nacisków i okoliczności, uczestniczyła w walce przeciwko apartheidowi. Także starała się nie skupiać na otwarcie antykomunistycznych walkach. Było to widać nie tylko w jej niechęci do sprzymierzania się z opozycją antysandinistyczną w Nikaragui, ale także we współpracy z lewicową opozycją z Chile. W ten sposób Solidarność mogła uniwersalizować swoją sprawę, przeciwstawiając się polaryzacji ładu zimnowojennego oraz pokazać, że była częścią ogólnej walki antytotalitarnej.

\section{Solidarność and the Third World. Part Two. Tactical Alliances with Key Movements of the 1980s}

The Polish crisis of the 1980s did not happen in isolation. Quite a number of countries in the Global South witnessed, more or less simultaneously with Poland and other Eastern European countries, an expanding civil resistance against authoritarian rule of both right-wing and left-wing stock. This article examines the connections that linked Solidarność in real and imagined terms with other international issues and social movements during the 1980s. The second and final part focuses on the networks of the Solidarność Coordinating Office Abroad from 1982 onwards and illustrates the ambivalent reaction towards the Contra-War in Nicaragua, the Pinochet dictatorship in Chile, and the anti-apartheid struggle in South Africa. In doing so, we cover the relationship of Solidarność with three global causes célèbres that dominated the international headlines and provoked a series of campaigns simultaneously with the Polish crisis.

All in all, contacts established with social or political movements in the Third World were rather limited. They mainly proceeded through the networks of a handful of leading representatives and were preponderantly mediated by their Western allies. They paled in intensity and scope in comparison with the multiple networks Solidarność and its representatives developed with allies in the West. And they were highly selective. Solidarność only embraced causes that were instrumental to its international profile. It reluctantly, and mainly pushed by external pressure and circumstances, sided with the anti-apartheid struggle. It also avoided explicitly anti-communist groups. This became not only clear in its reluctance to side with the anti-Sandinista opposition in Nicaragua, but also in its collaboration with the left-wing opposition from Chile. In this way, Solidarność could universalize its cause, defy Cold War bipolarity, and demonstrate that it was part of a general anti-totalitarian struggle. 


\section{Bibliografia}

1989 in a Global Perspective, ed. U. Engel, F. Hadler, M. Middell, Leipzig 2015.

Ackerman P., DuVall J., A Force More Powerful. A Century of Non-Violent Conflict, New York 2001.

Adam H., Moodley K., The Opening of the Apartheid Mind. Options for the New South Africa, Berkeley 1993.

Aufbruch nach Nicaragua. Deutsch-deutsche Solidarität im Systemwettstreit, Hrsg. E. Harzer, W. Volks, Berlin 2008.

Bizzarro S., Historical Dictionary of Chile, Lanham 2005.

Bois F. du, Bois-Pedain A. du, Post-Conflict Justice and the Reconciliatory Paradigm: the South African Experience in Context, w: Justice and Reconciliation in Post-Apartheid South Africa, ed. F. du Bois, A. du Bois-Pedain, Cambridge 2009, s. 289-311.

Brier R., Poland's Solidarity as a Contested Symbol of the Cold War: Transatlantic Debates After the Polish Crisis, w: European Integration and the Atlantic Community in the 1980s, ed. K.K. Patel, K. Weisbrode, New York 2013, s. 83-103.

Christiaens K., Globalizing Nicaragua? An Entangled History of Sandinista Solidarity Campaigns in Western Europe, w: Making Sense of the Americas. How Protest Related to America in the 1980s and Beyond, ed. J. Hansen, C. Helm, F. Reichherzer, Frankfurt-Chicago 2015, s. 155-177.

Christiaens K., Goddeeris I., Goedertier W., Inspirées par le Sud? Les mobilisations transnationales Est-Ouest pendant la guerre froide, „Vingtième Siècle, Revue d'Histoire” 2011, no. 109 , s. $155-168$.

Christiaens K., The Difficult Quest for Chilean Allies. International Labor Solidarity Campaigns for Chile in the 1970s and 1980s, w: European Solidarity with Chile, 1970s-1980s, ed. K. Christiaens, I. Goddeeris, M. Rodríguez García, Frankfurt am Main 2014, s. 97-129.

Dealing with the Past: truth and reconciliation in South Africa, ed. A. Boraine, J. Levy, R. Scheffer, Rondebosch 1994.

Edwards J., Chile: El dificil retorno a la democracia, „Revista de la Universidad de México”, II 1984, nro. 34, s. 12-15.

Evans M., Broadcasting the End of Apartheid. Live Television and the Birth of the New South Africa, London-New York 2014.

Exiliados, emigrados y retornados. Chilenos en América y Europa, 1973-2004, ed. J. del Pozo, Santiago 2006.

Gasztold-Seń P., Biznes z terrorystami. Brudne interesy wywiadu wojskowego PRL $z$ bliskowschodnimi organizacjami terrorystycznymi, „Pamięć i Sprawiedliwość” 2014, nr 1, s. $165-216$.

Gildea R., Mark J., Pas N., European Radicals and the 'Third World', „Cultural and Social History" 2011, vol. VIII, no. 4, s. 449-471.

Goddeeris I., Ministerstwo Spraw Zagranicznych „Solidarności”: Biuro Koordynacyjne NSZZ „Solidarność”, 1982-1989, cz. 1, „Pamięć i Sprawiedliwość” 2006, nr 2, s. 315-347.

Goddeeris I., The limits of lobbying: ILO and Solidarność, w: ILO Histories. Essays on the International Labour Organization and its Impact on the World during the Twentieth Century, ed. J. Van Daele, M. Rodríguez García, G. Van Goethem, M. van der Linden, Bern 2010, s. 423-441.

Gradskova Y., The Soviet Union: 'Chile is in Our Hearts.' Practices of Solidarity between Propaganda, Curiosity, and Subversion, w: European Solidarity with Chile, 1970s-1980s, ed.

K. Christiaens, I. Goddeeris, M. Rodríguez García, Frankfurt am Main 2014, s. 329-346.

Grass G., Im Hinterhof. Bericht über eine Reise nach Nicaragua, „Die Zeit”, 1 X 1982.

Harmer T., Allende's Chile and the Inter-American Cold War, Chapel Hill 2011. 
Hart G., For our Freedom and Yours. Za nasza i wasza wolność, London 1995.

Hite K., When the Romance Ended: Leaders of the Chilean Left, 1968-1998, New York 2000. Kenney P., A Carnival of Revolution. Central Europe 1989, Princeton-Oxford 2002.

Konopka T., Chile i Polska. Rozmowa z Carlosem Lima, „Widnokrag” 1987, nr 6/7, s. 58-65. Kornbluh P., The Pinochet File. A Declassified Dossier on Atrocity and Accountability, New York 2013.

Michnik A., Letters from Prison and other Essays, Berkeley 1987.

Muñoz H., The Dictator's Shadow. Life Under Augusto Pinochet, New York 2006.

Oushakine S.A., The Terrifying Mimicry of Samizdat, „Public Culture” 2001, vol. 13, no. 2, s. $191-214$.

Phelps M., Solidarność in Łódź: An Interview with Zbigniew Marcin Kowalewski, „International Labor and Working-Class History" 2008, vol. LXXIII, no. 1, s. 106-139.

Pieper Mooney J.E., East Germany: Chilean Exile and the Politics of Solidarity in the Cold War, w: European Solidarity with Chile, 1970s-1980s, ed. K. Christiaens, I. Goddeeris, M. Rodríguez García, Frankfurt am Main 2014, s. 275-300.

Rakowski M.F., Dzienniki polityczne 1984-1986, Warszawa 2005.

Rathkolb O., Austria: An Ambivalent Attitude of Trade Unions and Political Parties, w: Solidarity with Solidarity. Western European Trade Unions and the Polish Crisis, 1980-1982, ed. I. Goddeeris, Lanham 2010, s. 269-288.

Samsel R., Dotrzeć do bunkra Somozy, Warszawa 1980.

Scholte J.A., Anti-Apartheid and the Emergence of a Global Civil Society, „Acta Sociologica” 2007, vol. L, no. 3, s. 341-342.

Scott Christofferson M., French Intellectuals Against the Left. The Antitotalitarian Moment of the 1970s, New York 2004.

Shubin V., Traikova M., There is no threat from the Eastern Bloc, w: The Road to Democracy in South Africa, vol. III: International Solidarity, Part 2, Pretoria 2008, s. 985-1066.

Spooner M.H., Soldiers in a Narrow Land: The Pinochet Regime in Chile, Berkeley 1999.

Stola D., Kraj bez wyjścia? Migracje z Polski 1949-1989, Warszawa 2010.

Urquijo J.I., El movimiento obrero de Venezuela, Lima 2004.

Victims of the Chilean Miracle. Workers and Neoliberalism in the Pinochet Era, 1973-2002, ed. P. Winn, Durham-London 2004.

Walker I., Socialismo y democracia: Chile y Europa en perspectiva comparada, Santiago 1990.

Biogram: Kim Christiaens - prof. dr; historyk, dyrektor KADOC (Documentation and Research Center on Religion Culture and Society) na Uniwersytecie w Leuven (KU Leuven, Belgia). Specjalista z zakresu ruchów społecznych (związków zawodowych, organizacji solidarnościowych, NGO ds. praw człowieka itp.), zimnej wojny oraz religii w XX w. Pisał m.in. do „Contemporary European History” (2017), „Archiv für Sozialgeschichte” (2016) oraz „Journal of Contemporary History” (2015). E-mail: kim.christiaens@kuleuven.be.

Bi o g r a m: Idesbald Goddeeris - prof. dr; slawista oraz historyk, wykładowca na Uniwersytecie w Leuven (KU Leuven, Belgia). Specjalista z zakresu historii migracji, zimnej wojny oraz (post)kolonializmu. Autor książek na temat historii polskiej, emigracji polskiej w Belgii, UB/SB oraz Belgii itp. Redaktor Solidarity with Solidarity: Western European Trade Unions and the Polish Crisis, 1980-1982 (The Harvard Cold War Studies Book Series; Lanham 2010, paperback 2013). E-m ail: idesbald.goddeeris@kuleuven.be. 